\title{
INTRAVENOUS INJECTIONS
}

\author{
A Study of the Composition of the Blood During Continuous \\ Trauma to the Intestines When No Fluid is Injected and \\ When Fluid is Injected Continuously
}

By J. W. BEARD AND ALFRED BLALOCK

(From the Department of Surgery, Vanderbilt University, Nashoille)

(Received for publication September 3, 1931)

It is well known that the volume of circulating blood is reduced in shock. If the reduction is so great that the loss cannot be compensated for by further vasoconstriction, a decline in the arterial blood pressure results. There are two methods by which the blood pressure may be raised. First, drugs that cause the arterioles to constrict may be injected. The pressure in the larger arteries rises but the effect on the blood supply to an organ may be decreased by the constriction of the arterioles in that organ. Since an increase in the supply of blood to the tissues and not a high blood pressure is the primary object in view, the use of vasoconstrictor drugs is usually unsatisfactory. Second, fluids may be injected intravenously in an effort to increase both the blood volume and the blood pressure.

Solutions of widely varied physical and chemical characteristics have been used in the treatment of shock. The results obtained by the intravenous administration of fluids, other than whole blood or possibly gum acacia, have not been encouraging. Cannon (1) states, "All the evidence, both clinical and experimental, indicates that the intravenous injection of normal salt solution or Ringer's solution has only a temporary effect. The injected fluid promptly passes into the tissue spaces and within a brief period the pressure is as low as before, if not lower." The rapid loss of solutions of crystalloids from the blood stream explains the transitory beneficial effects of the injection but does not explain why the condition of the patient should of ten be worse shortly after the administration of fluid than it was before. The experiments described in this paper were undertaken for the purpose of finding an explanation for this observation. The studies have been extended to a comparison of the effects of the administration of various fluids that are commonly used in the treatment of shock.

The studies consisted in the main of repeated determinations of the amount and composition of the plasma in the blood stream under the various conditions. Alterations in the content in protein of the blood 
serum will be particularly emphasized. Trauma to the intestines was chosen as the method of producing shock because the trauma could be continuous and fluid could be recovered from the peritoneal cavity as frequently as desired for study.

\section{METHOD}

Dogs were used in all experiments. They were profoundly anesthetized by sodium barbital ( 0.3 gram per kilogram of body weight administered intravenously) and gave no evidence of pain during the experiments, at the completion of which they were killed. After making a long midline abdominal incision, the intestines were traumatized (2) by passing them continuously between the fingers. The trauma resulted in a copious weeping of fluid from the peritoneal surfaces. The intestines were not withdrawn from the peritoneal cavity during the traumatization and the fluid that accumulated there was collected frequently for study.

The blood pressure was determined by placing in the carotid artery a cannula that was connected to a mercury manometer. Blood for the various analyses was withdrawn from one of the femoral veins and it was replaced by an equal quantity of blood that was obtained from a normal dog. Samples of blood were obtained before the trauma was begun and at approximately one and one-half hour intervals thereafter until the blood pressure had declined to a low level with the exception of experiment $\mathrm{T} 17$. Urine was collected, at the same time that the samples of blood were withdrawn, through a catheter that was placed in the bladder. The animal was kept warm by the use of a heating pan.

The nitrogen content of the blood serum, the peritoneal fluid and the urine was determined. In the studies on the blood serum and the peritoneal fluid, the nitrogen was partitioned in most of the experiments. The nonprotein nitrogen was estimated by the method of Folin and Wu (3) except in those experiments in which the effects of concentrated solutions of glucose or gum acacia were being studied; in these the macro-Kjeldahl method was used. Albumin and globulin were separated by the use of 22.2 per cent sodium sulphate as recommended by Howe (4). Two cc. samples of serum and fluid were analyzed instead of $0.5 \mathrm{cc}$. samples and the dilutions with the sodium sulphate solutions were proportionately the same. Fifty of the resulting $62 \mathrm{cc}$. were chosen as the aliquot parts. The nitrogen of the albumin and of the total protein were determined by the Gunning (5) modification of the Kjeldahl method. The total nitrogen of the urine was also determined by this method. In all the tables the nitrogen is expressed as protein.

Van Allen tubes were used in the hematocrit determinations. The method of Cohen and Smith (6) was employed for the estimation of the hemoglobin. The initial blood volume of the animal was assumed to be 10 per cent of the body weight and on this basis the original volumes of red blood cells and plasma were calculated by the use of the hematocrit readings. In some experiments both hemoglobin and hematocrit determinations were performed, while in others the hemoglobin was not determined. If the hemoglobin and red blood cell count were both determined, the alterations in the total blood volume were assumed to vary in an inverse ratio to the changes in the percentage of hemoglobin. Having determined the alteration in the total blood volume, the volumes of red blood cells and plasma were calculated from the hematocrit readings. When only hematocrit determinations were performed, it was assumed that the volume of red blood cells remained constant throughout 
the experiments and the alterations in the volume of plasma were computed from the changes in hematocrit readings. The figures for the entire amount of protein were obtained by multiplying the percentage of protein per unit volume of serum by the total amount of plasma. No attempt was made to determine the alterations in the blood volume and in the entire amount of protein in the experiments in which the whole blood was injected. It is realized that the methods of calculation are only relatively accurate. The main error is introduced by the fact that the volume of red blood cells did not remain constant since some red blood cells escaped with the plasma into the peritoneal cavity and others accumulated in the traumatized area.

In the experiments in which fluid was introduced intravenously, it was injected at body temperature at a constant rate into either the external jugular or femoral vein. The amount of fluid that was given was approximately $10 \mathrm{cc}$. per kilogram of body weight per hour. The following fluids were used in the different experiments: (1) 0.9 per cent salt solution, (2) 3.0 per cent salt solution, (3) 6.0 per cent glucose, (4) 20 per cent glucose, (5) 6.0 per cent gum acacia, (6) Evans' solution of 6.0 per cent gum acacia and 20 per cent glucose in 0.9 per cent salt solution, (7) blood serum and (8) whole blood.

In most of the experiments in which fluid was injected, the water content of the blood and of skeletal muscle was determined by drying the tissue at $105^{\circ} \mathrm{C}$. to a constant weight. Blood was collected from the femoral vein. Skeletal muscle was obtained from the pectoral and one of the flexor muscles of the thigh at the beginning of the experiments and from symmetrical sites on the opposite side of the body at the completion.

\section{RESULTS}

\section{CONTINUOUS TRAUMA TO THE INTESTINES. NO FLUID INJECTED}

When the intestines were traumatized continuously the animals usually lived six or seven hours. The decline in blood pressure was more rapid towards the end of the experiment than at the beginning. The hematocrit determinations showed a progressive increase in the proportion of red blood cells to plasma throughout the experiments. The calculated volume of plasma decreased until at the completion of the experiments it was approximately one-half of its original value. The calculated total protein content of the blood serum remained approximately the same throughout the experiments and the corresponding fluid from the peritoneal cavity on analysis showed a content in protein very nearly the same as that of the serum. The percentages of albumin and of globulin in the blood serum were altered very little during the course of the experiments. The content in albumin of the peritoneal fluid was greater than that of the blood serum, whereas the content in globulin of the peritoneal fluid was usually less than that of the serum. Since the volume of plasma was greatly diminished, the absolute amounts of total protein, albumin and globulin in the blood stream were considerably reduced.

The results of three typical experiments are given in Table I. 


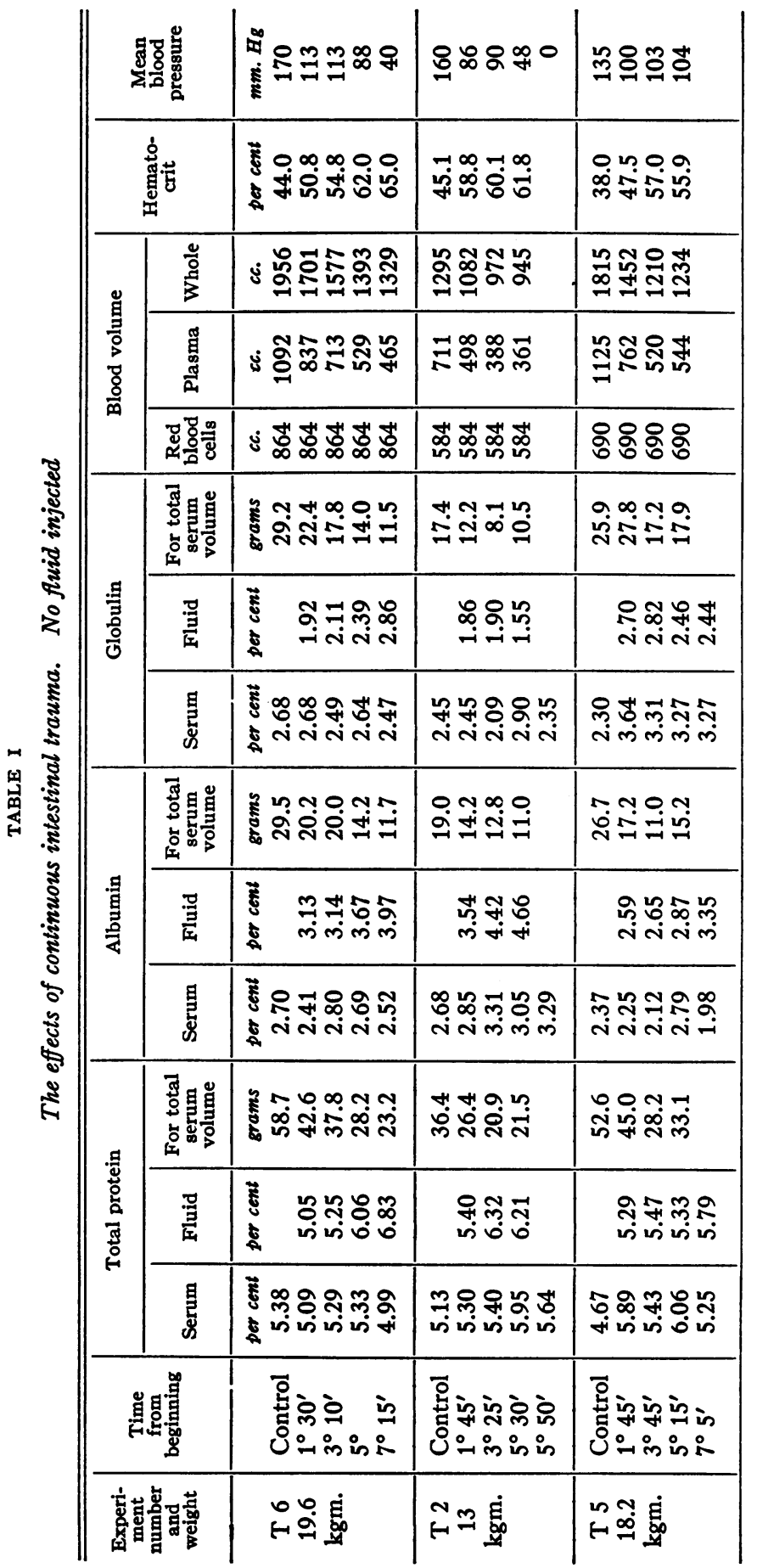




\section{CONTINUOUS TRAUMA TO THE INTESTINES. CONTINUOUS INJECTION OF FLUID}

The amounts of fluid injected into the veins of each of the animals in these experiments were excessive. However, determinations were performed frequently during the experiments and the effects of small as well as large amounts of fluid are to be seen in the results in the tables. The average survival period of the animals in these experiments was approximately the same as that in the experiments in which the intestines were traumatized and no fluid was introduced. The type of fluid that was injected in these experiments did not seem to alter considerably the length of life of the animals. The longest survival period was encountered in $\operatorname{dog} \mathrm{T} 17$ in which the intestines were traumatized and whole blood was injected for seven and one-half hours. At the end of this time the blood pressure was essentially normal, but the animal died three hours later. The alterations in the percentage of hemoglobin paralleled fairly closely the changes in the hematocrit readings. In many experiments a dilution of the blood occurred just before death. In all experiments in which the nitrogen of the control specimen of urine was determined as well as that obtained later, it was found that the urine collected during the control period had the higher total protein equivalent. In most of the experiments the amount of nitrogen that was lost in the urine was very small. In all of these experiments the intestines were traumatized continuously.

The effects of the different solutions employed were briefly as follows. The detailed results of one experiment in each group are given in Table II. Because of lack of space, the others are not included.

\section{The injection of 0.9 per cent salt solution}

Four experiments of this type were performed. Associated with the trauma and the injection of large amounts of salt solution there was an increase in the proportion of red blood cells to plasma in all of the experiments. The calculated total volume of blood plasma decreased. The percentage of protein per unit volume of serum decreased markedly in all experiments except $\mathrm{T} 48$, in which there was very little alteration. The calculated entire amount of protein in the blood stream at the completion of the experiments was approximately one-half of the original values. There was a decrease in the concentration of albumin and globulin. The content in albumin of the peritoneal fluid was greater than that of the blood serum while the globulin content of the serum was greater than that of the fluid.

\section{The injection of 3.0 per cent salt solution}

In three of the four experiments, the injection of 3.0 per cent salt solution while the intestines were being traumatized was associated with 


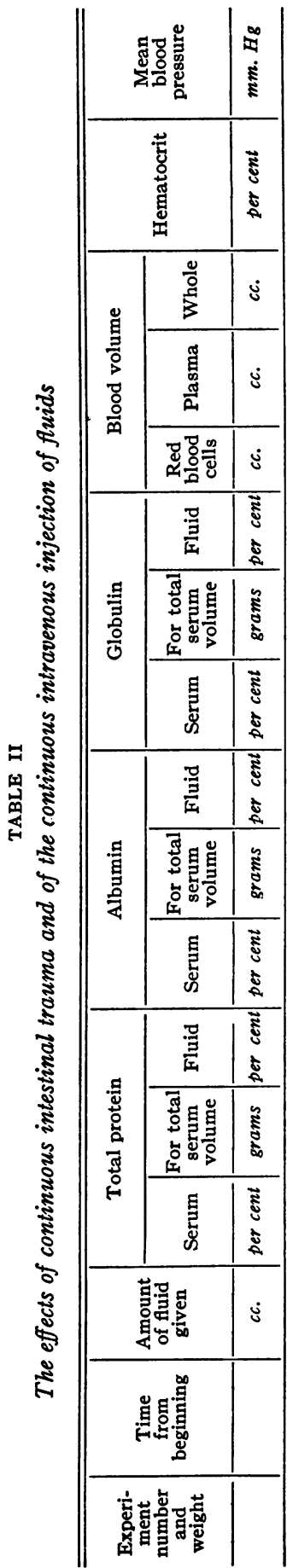

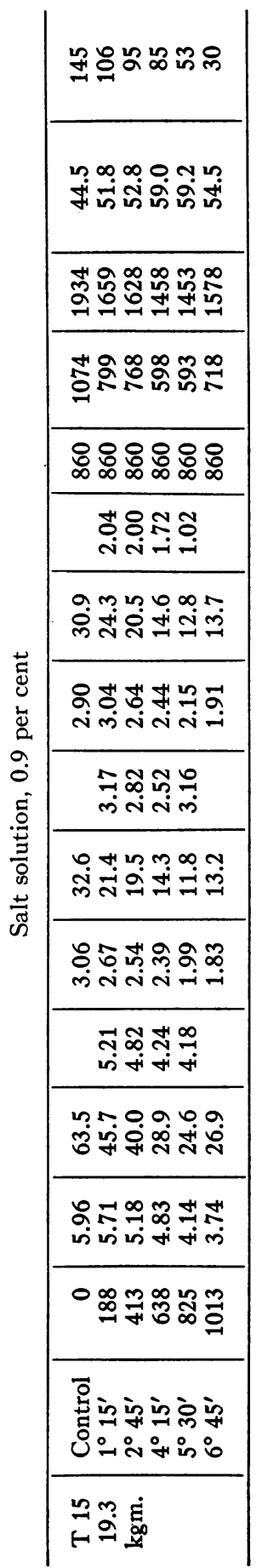

\begin{tabular}{|c|c|c|}
\hline 뉵음ㅇㅇㄴ & \multirow{17}{*}{ 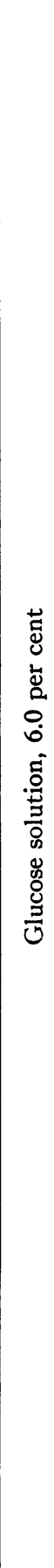 } & 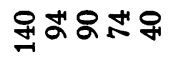 \\
\hline 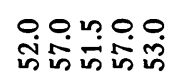 & & n̊요 \\
\hline 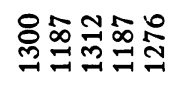 & & 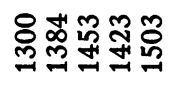 \\
\hline 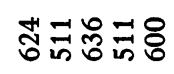 & & 苂冓命会 \\
\hline 융늉늉융 융 & & 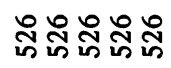 \\
\hline ?ْ & & 帒 \\
\hline 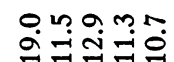 & & 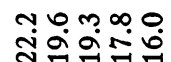 \\
\hline 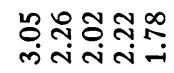 & & ن \\
\hline 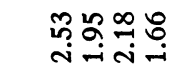 & & 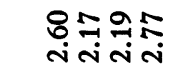 \\
\hline ํㅜㅇำ & & 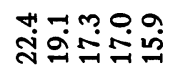 \\
\hline 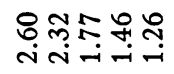 & & 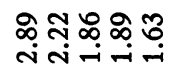 \\
\hline 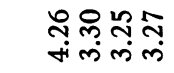 & & 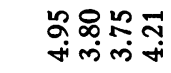 \\
\hline 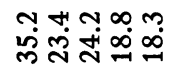 & & 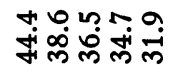 \\
\hline 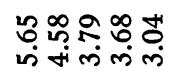 & & 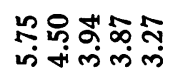 \\
\hline 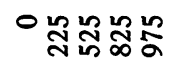 & & 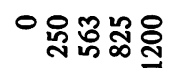 \\
\hline 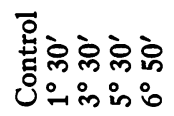 & & 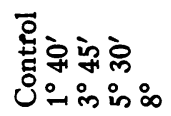 \\
\hline$\vec{N} \cong \dot{\dot{E}_{0}}$ & & 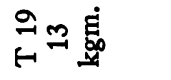 \\
\hline
\end{tabular}




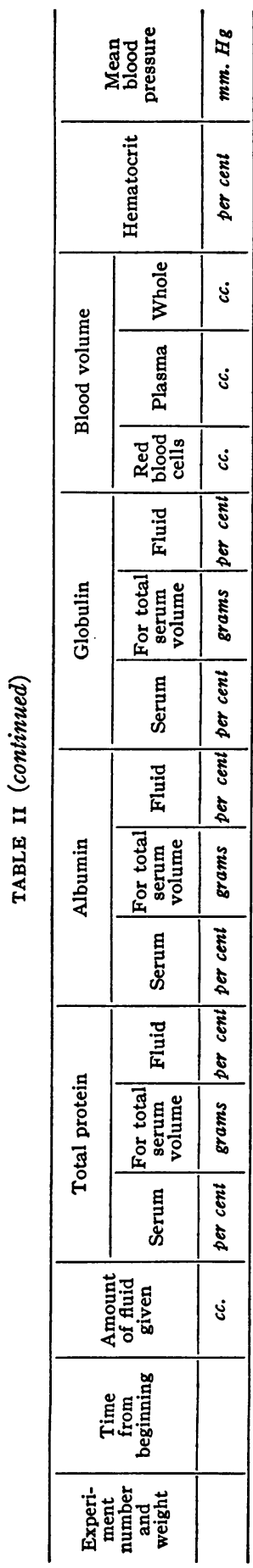

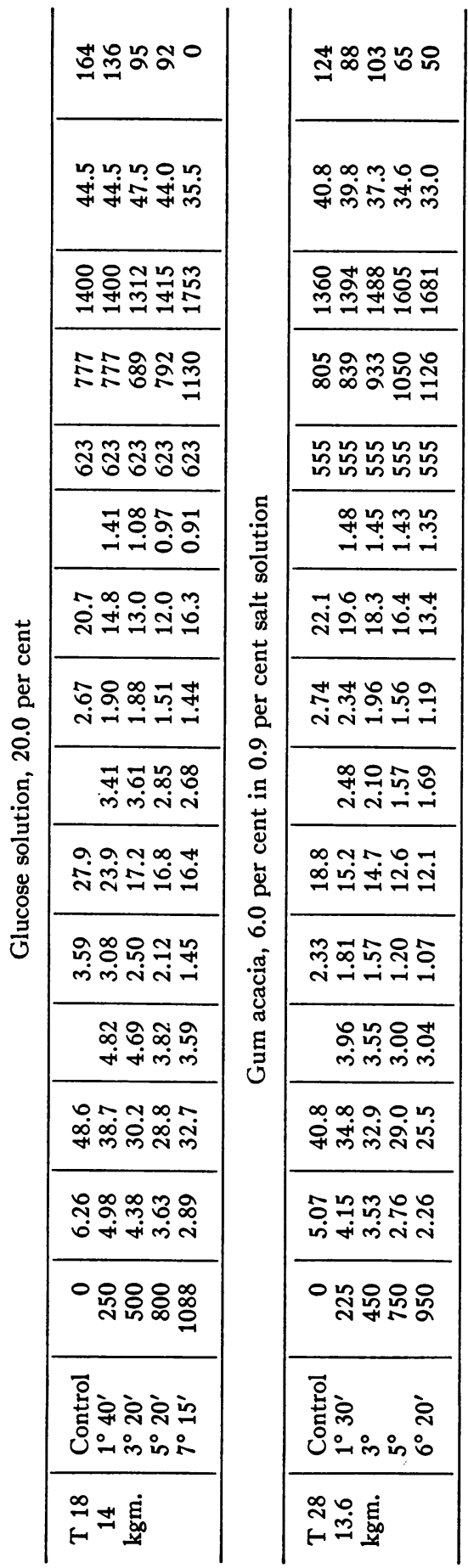

\begin{tabular}{|c|}
\hline 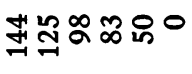 \\
\hline 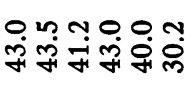 \\
\hline 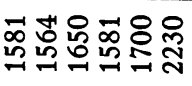 \\
\hline 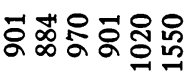 \\
\hline :্ర్ర: \\
\hline 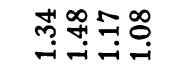 \\
\hline 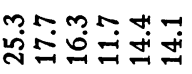 \\
\hline 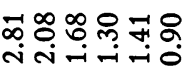 \\
\hline 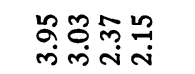 \\
\hline 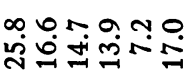 \\
\hline 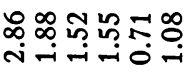 \\
\hline 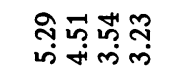 \\
\hline 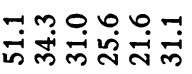 \\
\hline 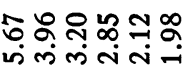 \\
\hline 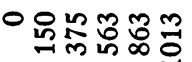 \\
\hline 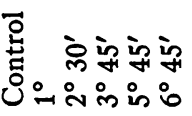 \\
\hline 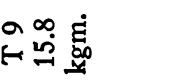 \\
\hline
\end{tabular}




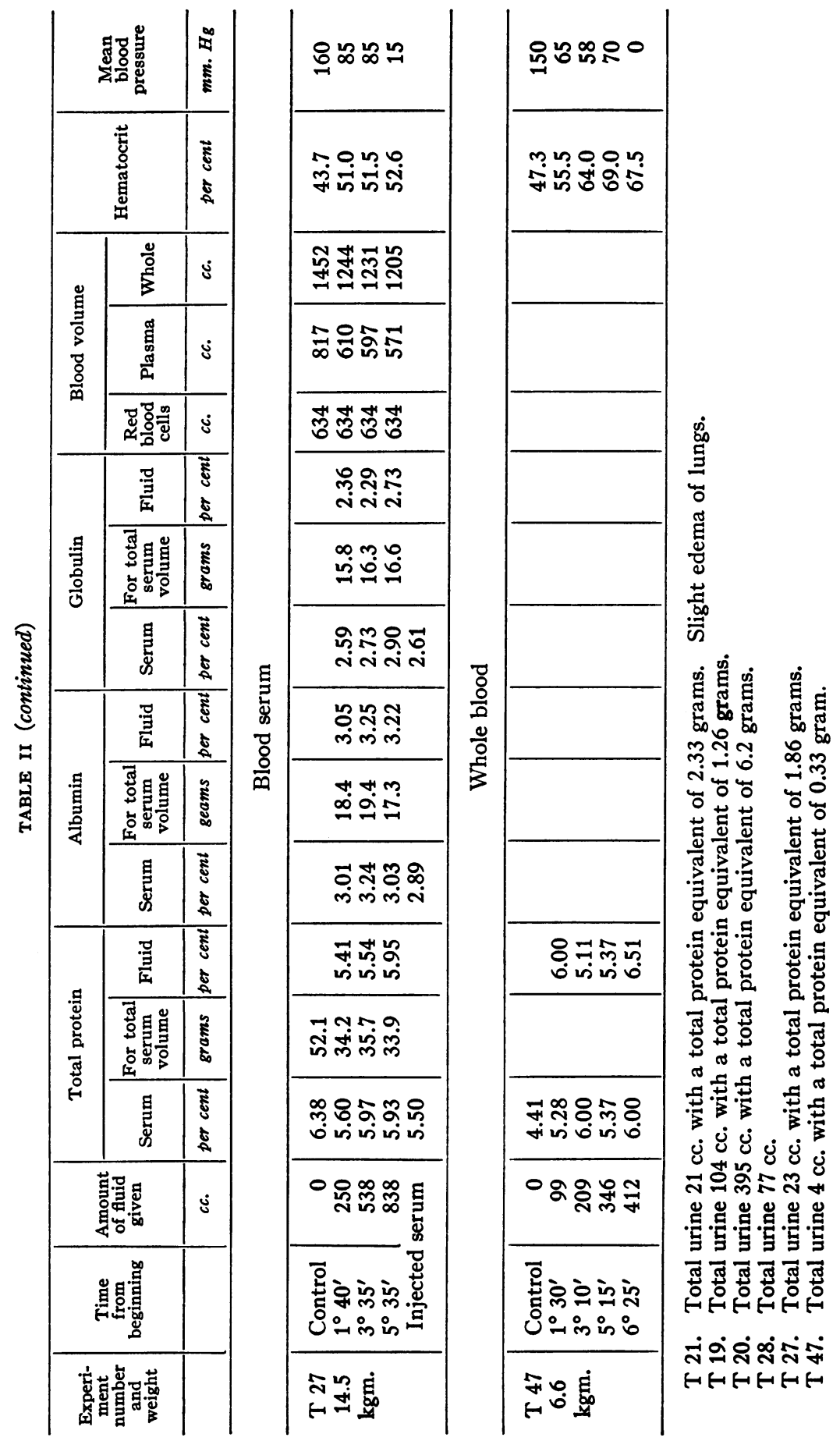


an increase in the concentration of red blood cells. The calculated volume of plasma decreased in three of the four experiments. In all experiments there was a decrease in the percentage of total protein, of albumin and of globulin with a diminution in the calculated entire amount of each in the blood stream. The content in albumin of the peritoneal fluid was slightly greater than that of the blood serum, while the globulin content of the serum was greater than that of the fluid.

\section{The injection of 6.0 per cent glucose solution}

In three of the four experiments there was an increase in the proportion of red blood cells to plasma. In one experiment the volume of plasma increased and in three it decreased. In all experiments there was a decrease in the percentage and in the calculated entire amount of total protein, albumin and globulin. The albumin content of the peritoneal fluid was usually greater than that of the blood serum, while the globulin content of the serum was greater.

\section{The injection of 20 per cent glucose solution}

A concentration of the blood occurred during the early part of the three experiments. During the later stages of two of the experiments, a dilution of the blood took place. There was a marked diminution in the concentration of total protein, albumin and globulin in all instances and the calculated entire amount of each in the blood stream was greatly decreased. There was a higher percentage of albumin and a lower percentage of globulin in the blood serum than in the peritoneal fluid.

\section{The injection of 6.0 per cent gum acacia solution}

If six per cent gum acacia in normal salt solution was injected during the trauma, there was an increase in the concentration of the blood at the end of an hour and a half in two of the three experiments. Later observations showed a definite dilution of the blood. There was a marked decrease in the total protein, albumin and globulin per unit volume of serum. Even though there was an increase in the calculated total volume of plasma in most of the experiments the total amount of the protein constituents in the blood stream was markedly diminished. The amount of gum acacia that remained in the circulation was not determined.

\section{The injection of 6.0 per cent gum acacia and 20.0 per cent glucose in 0.9 per cent normal salt solution}

In all experiments there was a marked dilution of the red blood cells and a large increase in the volume of plasma in the blood stream. The percentages of total protein, of albumin, and of globulin per unit volume of serum and the calculated entire amounts of each in the blood stream were decreased in all experiments. The concentration of albumin in the 
peritoneal fluid was greater and the concentration of globulin was less than in the blood serum.

\section{The injection of blood serum}

Even though blood serum was injected continuously, the concentration of red blood cells increased in two of the three experiments. The content of total protein, of albumin, and of globulin in the blood serum remained approximately the same throughout the course of the experiments. In two of the three experiments there was a decrease in the calculated entire amount of protein in the blood stream. Since protein was present in the blood serum that was being injected, the true loss of protein was greater than the apparent loss. For example, in experiment $T 27$, the calculated entire amount of protein in the blood stream before the trauma was instituted was $\mathbf{5 2}$ grams. Five and one-half hours later it was 34 grams, indicating a loss of 18 grams. But during this time 46 grams of protein had been injected so that the true loss was 64 grams rather than 18.

\section{The injection of whole blood}

The concentration of the red blood cells increased tremendously in the three experiments in which whole blood was injected. No attempt was made to estimate the alterations in the volume of circulating blood but we can be quite certain that the volume of plasma was reduced even though whole blood was injected. The concentration of total protein, albumin and globulin in the blood serum either remained the same or increased slightly during the course of the studies. The results of these experiments differ from those obtained after the injection of blood serum. There was a much more decided increase in the concentration of the red blood cells.

\section{WATER CONTENT OF BLOOD AND MUSCLE}

As has been stated previously, the water contents of blood and of skeletal muscles were determined in experiments in which the intestines were traumatized and various fluids were injected. The effects of intestinal trauma alone had been determined in previous experiments by Harris and Blalock (7). In the experiments in which normal salt solution was introduced there was a slight decrease in the water content of the blood. In those in which gum acacia solutions were used there was a definite increase in the water content of the blood and in those in which whole blood was injected there was a rather large decrease. The alterations that were found in the experiments in which 3.0 per cent salt solution, 6.0 per cent glucose, 20.0 per cent glucose and blood serum were injected were negligible. In the experiments in which the solution of gum acacia and glucose was injected a definite increase in the water content of muscle was found. When 20.0 per cent glucose was injected, a slight 
decrease resulted. With these two exceptions the alterations in the water content of skeletal muscle were of too small magnitude to be of importance.

The results of the determinations on the water content of blood and muscle in the various experiments are given in Table III.

\section{DISCUSSION}

When the intestines are passed continuously between the fingers, a copious weeping of fluid from the peritoneal surfaces results. In a previous communication (8) studies of the composition of this fluid were reported. It was found among other things that the protein content of the fluid was approximately the same as that of the blood plasma. Those studies did not include determinations of the albumin and globulin content of the fluid. It has been found in this study that the albumin content of the peritoneal fluid was greater than that of the blood serum while the globulin content of the fluid was less than that of blood serum. When fluids were injected continuously while the intestines were being traumatized, usually this same relationship between the blood serum and the peritoneal fluid was found. It is doubtful if the high percentage of albumin in the fluid was due entirely to concentration as a result of evaporation. Possibly trauma resulted in the loss of some of the proteins of the fixed tissues into the fluid. If it is assumed that the osmotic pressure in the capillaries and in the tissue spaces of the injured intestines were the same, then it is apparent that there would be no force resisting the filtration pressure in the vessels of the damaged area and that large amounts of fluid would be expressed.

It is of particular interest in these experiments that the percentage of protein, albumin and globulin per unit volume of serum remained practically constant throughout the period in which the intestines were traumatized and no fluid was injected and that it decreased considerably in most of the experiments in which fluids other than blood and serum were introduced. A careful review of the literature did not reveal any experiments closely similar to the present studies. White and Erlanger (9) determined in three experiments the effects of the injection of a strongly hypertonic solution of gum acacia and glucose into animals in shock as a result of partial occlusion of the inferior vena cava. In their experiments the injection was not continuous and the effects of only one solution were determined. In summarizing their results, they state, "The blood volume, markedly diminished in shock, is increased to above its normal level by the injection and then falls to or below its normal level. . . . The absolute amount of plasma protein is markedly diminished in shock, is increased by the injection and the increase continues for some time after the injection. It is believed that at least a part of the increase in plasma protein following the injection in shock is due to a passage of protein in through the vessel walls." 
TABLE III

The effects of continuous intestinal trauma and the continuous administration of fluids on the water content of blood and muscles

\begin{tabular}{|c|c|c|c|c|c|c|c|}
\hline \multirow{2}{*}{ Fluid given } & \multirow{2}{*}{ Time } & \multirow{2}{*}{$\begin{array}{c}\text { Amount } \\
\text { of fluid } \\
\text { given }\end{array}$} & \multirow{2}{*}{$\begin{array}{l}\text { Blood } \\
\text { pressure }\end{array}$} & \multirow{2}{*}{$\underset{\text { crit }}{\text { Hemato- }}$} & \multicolumn{3}{|c|}{ Water } \\
\hline & & & & & Blood & $\begin{array}{c}\text { Pectoral } \\
\text { muscle }\end{array}$ & $\begin{array}{l}\text { Thigh } \\
\text { muscle }\end{array}$ \\
\hline $\begin{array}{r}\text { per cent } \\
0.9 \text { Saline..... }\end{array}$ & $\begin{array}{l}\text { Control } \\
6^{\circ} 45^{\prime}\end{array}$ & $\begin{array}{r}c c . \\
0 \\
1013\end{array}$ & $\begin{array}{c}m m . \mathrm{Hg} \\
145 \\
30\end{array}$ & $\begin{array}{c}\text { per cent } \\
44.5 \\
54.5\end{array}$ & $\begin{array}{c}\text { per cent } \\
80.40 \\
77.50\end{array}$ & $\begin{array}{c}\text { per cent } \\
74.05 \\
75.40\end{array}$ & $\begin{array}{c}\text { per cent } \\
73.15 \\
72.60\end{array}$ \\
\hline 0.9 Saline. . & $\begin{array}{l}\text { Control } \\
3^{\circ} 15^{\prime}\end{array}$ & $\begin{array}{r}0 \\
488\end{array}$ & $\begin{array}{r}156 \\
48\end{array}$ & $\begin{array}{l}51.2 \\
53.0\end{array}$ & $\begin{array}{l}79.20 \\
77.60\end{array}$ & $\begin{array}{l}75.40 \\
75.20\end{array}$ & $\begin{array}{l}74.35 \\
74.00\end{array}$ \\
\hline 0.9 Saline. . & $\begin{array}{l}\text { Control } \\
7^{\circ} 30^{\prime}\end{array}$ & $\begin{array}{r}0 \\
1260\end{array}$ & $\begin{array}{r}130 \\
78\end{array}$ & $\begin{array}{l}50.5 \\
62.3\end{array}$ & $\begin{array}{l}77.80 \\
76.20\end{array}$ & $\begin{array}{l}76.30 \\
75.80\end{array}$ & $\begin{array}{l}74.55 \\
74.20\end{array}$ \\
\hline 0.9 Saline. & $\begin{array}{l}\text { Control } \\
7^{\circ}\end{array}$ & $\begin{array}{r}0 \\
1386\end{array}$ & $\begin{array}{r}160 \\
22\end{array}$ & $\begin{array}{l}52.4 \\
60.7\end{array}$ & $\begin{array}{l}76.40 \\
75.30\end{array}$ & $\begin{array}{l}70.60 \\
75.25\end{array}$ & $\begin{array}{l}68.95 \\
67.40\end{array}$ \\
\hline Average. & $\begin{array}{l}\text { Control } \\
\text { Later }\end{array}$ & & $\begin{array}{r}148 \\
45\end{array}$ & $\begin{array}{l}49.65 \\
57.63\end{array}$ & $\begin{array}{l}78.45 \\
76.65\end{array}$ & $\begin{array}{l}74.09 \\
75.41\end{array}$ & $\begin{array}{l}72.75 \\
72.05\end{array}$ \\
\hline 3.0 Saline. & $\begin{array}{l}\text { Control } \\
6^{\circ} 50^{\prime}\end{array}$ & $\begin{array}{r}0 \\
975\end{array}$ & $\begin{array}{r}156 \\
44\end{array}$ & $\begin{array}{l}52.0 \\
53.0\end{array}$ & $\begin{array}{l}77.20 \\
79.42\end{array}$ & $\begin{array}{l}73.35 \\
75.60\end{array}$ & $\begin{array}{l}73.00 \\
72.00\end{array}$ \\
\hline 3.0 Saline. . & $\begin{array}{l}\text { Control } \\
5^{\circ}\end{array}$ & $\begin{array}{r}0 \\
750\end{array}$ & $\begin{array}{r}136 \\
30\end{array}$ & $\begin{array}{l}33.0 \\
30.4\end{array}$ & $\begin{array}{l}83.00 \\
85.30\end{array}$ & $\begin{array}{l}77.18 \\
78.70\end{array}$ & $\begin{array}{l}75.05 \\
78.25\end{array}$ \\
\hline 3.0 Saline. . & $\begin{array}{l}\text { Control } \\
7^{\circ}\end{array}$ & $\begin{array}{r}0 \\
1148\end{array}$ & $\begin{array}{r}128 \\
0\end{array}$ & $\begin{array}{l}49.3 \\
54.2\end{array}$ & $\begin{array}{l}78.90 \\
79.10\end{array}$ & $\begin{array}{l}77.55 \\
74.30\end{array}$ & $\begin{array}{l}74.95 \\
74.60\end{array}$ \\
\hline 3.0 Saline. & $\begin{array}{l}\text { Control } \\
7^{\circ} 30^{\prime}\end{array}$ & $\begin{array}{r}0 \\
1095\end{array}$ & $\begin{array}{l}160 \\
105\end{array}$ & $\begin{array}{l}53.9 \\
61.3\end{array}$ & $\begin{array}{l}76.20 \\
75.90\end{array}$ & & $\begin{array}{l}70.70 \\
69.50\end{array}$ \\
\hline Average. & $\begin{array}{l}\text { Control } \\
\text { Later }\end{array}$ & & $\begin{array}{r}145 \\
45\end{array}$ & $\begin{array}{l}47.0 \\
49.7\end{array}$ & $\begin{array}{l}78.83 \\
79.93\end{array}$ & $\begin{array}{l}76.03 \\
76.30\end{array}$ & $\begin{array}{l}73.43 \\
73.59\end{array}$ \\
\hline 6.0 Glucose. . & $\begin{array}{l}\text { Control } \\
8^{\circ}\end{array}$ & $\begin{array}{r}0 \\
1200\end{array}$ & $\begin{array}{r}140 \\
40\end{array}$ & $\begin{array}{l}40.5 \\
35.0\end{array}$ & $\begin{array}{l}80.50 \\
84.30\end{array}$ & & $\begin{array}{l}63.15 \\
67.20\end{array}$ \\
\hline 6.0 Glucose. . & $\begin{array}{l}\text { Control } \\
4^{\circ}\end{array}$ & $\begin{array}{r}0 \\
600\end{array}$ & $\begin{array}{r}100 \\
35\end{array}$ & $\begin{array}{l}33.2 \\
37.5\end{array}$ & $\begin{array}{l}83.30 \\
83.05\end{array}$ & $\begin{array}{l}78.30 \\
76.58\end{array}$ & $\begin{array}{l}75.58 \\
76.62\end{array}$ \\
\hline 6.0 Glucose.... & $\begin{array}{l}\text { Control } \\
6^{\circ} 40^{\prime}\end{array}$ & $\begin{array}{r}0 \\
707\end{array}$ & $\begin{array}{r}130 \\
21\end{array}$ & $\begin{array}{l}41.7 \\
38.0\end{array}$ & $\begin{array}{l}80.95 \\
83.00\end{array}$ & $\begin{array}{l}75.60 \\
76.10\end{array}$ & $\begin{array}{l}73.55 \\
75.00\end{array}$ \\
\hline 6.0 Glucose. . & $\begin{array}{l}\text { Control } \\
7^{\circ}\end{array}$ & $\begin{array}{r}0 \\
896\end{array}$ & $\begin{array}{l}152 \\
100\end{array}$ & $\begin{array}{l}45.4 \\
54.0\end{array}$ & $\begin{array}{l}79.50 \\
78.10\end{array}$ & $\begin{array}{l}76.40 \\
75.00\end{array}$ & $\begin{array}{l}74.80 \\
73.70\end{array}$ \\
\hline Average. & $\begin{array}{l}\text { Control } \\
\text { Later }\end{array}$ & & $\begin{array}{r}131 \\
49\end{array}$ & $\begin{array}{l}40.2 \\
41.1\end{array}$ & $\begin{array}{l}81.06 \\
82.11\end{array}$ & $\begin{array}{l}76.77 \\
75.89\end{array}$ & $\begin{array}{l}71.77 \\
73.13\end{array}$ \\
\hline 20.0 Glucose. & $\begin{array}{l}\text { Control } \\
7^{\circ} 30^{\prime}\end{array}$ & $\begin{array}{r}0 \\
1125\end{array}$ & $\begin{array}{r}130 \\
40\end{array}$ & $\begin{array}{l}43.2 \\
59.0\end{array}$ & $\begin{array}{l}78.90 \\
75.45\end{array}$ & $\begin{array}{l}73.90 \\
73.20\end{array}$ & $\begin{array}{l}72.65 \\
72.60\end{array}$ \\
\hline 20.0 Glucose. & $\begin{array}{l}\text { Control } \\
7^{\circ} 15^{\prime}\end{array}$ & $\begin{array}{r}0 \\
1088\end{array}$ & $\begin{array}{r}164 \\
0\end{array}$ & $\begin{array}{l}44.5 \\
35.5\end{array}$ & $\begin{array}{l}79.00 \\
81.75\end{array}$ & $\begin{array}{l}75.62 \\
74.30\end{array}$ & $\begin{array}{l}73.88 \\
72.10\end{array}$ \\
\hline 20.0 Glucose. & $\begin{array}{l}\text { Control } \\
7^{\circ} 30^{\prime}\end{array}$ & $\begin{array}{r}0 \\
848\end{array}$ & $\begin{array}{r}130 \\
62\end{array}$ & $\begin{array}{l}48.8 \\
36.8\end{array}$ & $\begin{array}{l}78.25 \\
80.30\end{array}$ & $\begin{array}{l}75.55 \\
71.20\end{array}$ & $\begin{array}{l}74.60 \\
69.65\end{array}$ \\
\hline
\end{tabular}


TABLE III (continued)

\begin{tabular}{|c|c|c|c|c|c|c|c|}
\hline \multirow{2}{*}{ Fluid given } & \multirow{2}{*}{ Time } & \multirow{2}{*}{$\begin{array}{c}\text { Amount } \\
\text { of fluid } \\
\text { given }\end{array}$} & \multirow{2}{*}{$\begin{array}{c}\text { Blood } \\
\text { pressure }\end{array}$} & \multirow{2}{*}{$\begin{array}{c}\text { Hemato- } \\
\text { crit }\end{array}$} & \multicolumn{3}{|c|}{ Water } \\
\hline & & & & & Blood & $\begin{array}{l}\text { Pectoral } \\
\text { muscle }\end{array}$ & $\begin{array}{l}\text { Thigh } \\
\text { muscle }\end{array}$ \\
\hline $\begin{array}{r}\text { per cent } \\
\text { Average. }\end{array}$ & $\begin{array}{l}\text { Control } \\
\text { Later }\end{array}$ & $c c$. & $\begin{array}{c}\text { mm. } H g \\
141 \\
34\end{array}$ & $\begin{array}{c}\text { per cent } \\
45.5 \\
43.8\end{array}$ & $\begin{array}{c}\text { per cent } \\
78.72 \\
79.17\end{array}$ & $\begin{array}{c}\text { per cent } \\
75.02 \\
72.90\end{array}$ & $\begin{array}{c}\text { per cent } \\
73.71 \\
71.45\end{array}$ \\
\hline 6.0 Acacia. & $\begin{array}{l}\text { Control } \\
6^{\circ} 20^{\prime}\end{array}$ & $\begin{array}{r}0 \\
950\end{array}$ & $\begin{array}{r}124 \\
50\end{array}$ & $\begin{array}{l}40.8 \\
33.0\end{array}$ & $\begin{array}{l}80.90 \\
83.30\end{array}$ & $\begin{array}{l}78.25 \\
78.30\end{array}$ & $\begin{array}{l}77.25 \\
77.62\end{array}$ \\
\hline 6.0 Acacia. & $\begin{array}{l}\text { Control } \\
5^{\circ} 15^{\prime}\end{array}$ & $\begin{array}{r}0 \\
788\end{array}$ & $\begin{array}{r}150 \\
0\end{array}$ & $\begin{array}{l}39.8 \\
36.0\end{array}$ & $\begin{array}{l}80.10 \\
82.70\end{array}$ & $\begin{array}{l}75.55 \\
76.60\end{array}$ & $\begin{array}{l}70.30 \\
64.90\end{array}$ \\
\hline 6.0 Acacia. & $\begin{array}{l}\text { Control } \\
7^{\circ} 30^{\prime}\end{array}$ & $\begin{array}{r}0 \\
975\end{array}$ & $\begin{array}{r}140 \\
90\end{array}$ & $\begin{array}{l}38.8 \\
31.7\end{array}$ & $\begin{array}{l}80.00 \\
83.80\end{array}$ & $\begin{array}{l}75.80 \\
77.75\end{array}$ & $\begin{array}{l}74.85 \\
75.00\end{array}$ \\
\hline Average. & $\begin{array}{l}\text { Control } \\
\text { Later }\end{array}$ & & $\begin{array}{r}138 \\
47\end{array}$ & $\begin{array}{l}39.8 \\
33.6\end{array}$ & $\begin{array}{l}80.33 \\
83.27\end{array}$ & $\begin{array}{l}76.53 \\
77.55\end{array}$ & $\begin{array}{l}74.13 \\
72.51\end{array}$ \\
\hline Acacia, glucose, saline & $\begin{array}{l}\text { Control } \\
6^{\circ} 15^{\prime}\end{array}$ & $\begin{array}{r}0 \\
938\end{array}$ & $\begin{array}{r}154 \\
0\end{array}$ & $\begin{array}{l}53.0 \\
25.5\end{array}$ & $\begin{array}{l}77.70 \\
84.00\end{array}$ & $\begin{array}{l}75.45 \\
71.78\end{array}$ & $\begin{array}{l}74.85 \\
71.70\end{array}$ \\
\hline Acacia, glucose, saline & $\begin{array}{l}\text { Control } \\
6^{\circ} 45^{\prime}\end{array}$ & $\begin{array}{r}0 \\
1013\end{array}$ & $\begin{array}{r}144 \\
0\end{array}$ & $\begin{array}{l}43.0 \\
30.2\end{array}$ & $\begin{array}{l}79.50 \\
82.23\end{array}$ & $\begin{array}{l}70.15 \\
66.15\end{array}$ & $\begin{array}{l}72.00 \\
68.80\end{array}$ \\
\hline Acacia, glucose, saline & $\begin{array}{l}\text { Control } \\
7^{\circ} 30^{\prime}\end{array}$ & $\begin{array}{r}0 \\
840\end{array}$ & $\begin{array}{r}150 \\
38\end{array}$ & $\begin{array}{l}42.8 \\
30.0\end{array}$ & $\begin{array}{l}80.75 \\
83.75\end{array}$ & $\begin{array}{l}77.60 \\
75.20\end{array}$ & $\begin{array}{l}73.58 \\
69.90\end{array}$ \\
\hline Acacia, glucose, saline & $\begin{array}{l}\text { Control } \\
7^{\circ}\end{array}$ & $\begin{array}{r}0 \\
742\end{array}$ & $\begin{array}{r}130 \\
63\end{array}$ & $\begin{array}{l}43.0 \\
33.3\end{array}$ & $\begin{array}{l}79.95 \\
82.45\end{array}$ & $\begin{array}{l}75.20 \\
75.50\end{array}$ & $\begin{array}{l}74.25 \\
70.60\end{array}$ \\
\hline Average. & $\begin{array}{l}\text { Control } \\
\text { Later }\end{array}$ & & $\begin{array}{r}145 \\
25\end{array}$ & $\begin{array}{l}45.5 \\
29.8\end{array}$ & $\begin{array}{l}79.48 \\
83.36\end{array}$ & $\begin{array}{l}74.60 \\
72.16\end{array}$ & $\begin{array}{l}73.67 \\
70.25\end{array}$ \\
\hline Blood plasma & $\begin{array}{l}\text { Control } \\
5^{\circ} 35^{\prime}\end{array}$ & $\begin{array}{r}0 \\
838\end{array}$ & $\begin{array}{r}160 \\
15\end{array}$ & $\begin{array}{l}43.7 \\
52.6\end{array}$ & $\begin{array}{l}79.10 \\
77.50\end{array}$ & $\begin{array}{l}77.40 \\
76.30\end{array}$ & $\begin{array}{l}74.40 \\
73.35\end{array}$ \\
\hline Blood plasma. & $\begin{array}{l}\text { Control } \\
5^{\circ} 25^{\prime}\end{array}$ & $\begin{array}{r}0 \\
444\end{array}$ & $\begin{array}{r}123 \\
73\end{array}$ & $\begin{array}{l}42.2 \\
40.0\end{array}$ & $\begin{array}{l}80.50 \\
81.05\end{array}$ & $\begin{array}{l}75.20 \\
75.00\end{array}$ & $\begin{array}{l}72.40 \\
72.40\end{array}$ \\
\hline Blood plasma. & $\begin{array}{l}\text { Control } \\
4^{\circ} 45^{\prime}\end{array}$ & $\begin{array}{r}0 \\
427\end{array}$ & $\begin{array}{r}133 \\
0\end{array}$ & $\begin{array}{l}45.1 \\
47.0\end{array}$ & $\begin{array}{l}79.70 \\
79.40\end{array}$ & $\begin{array}{l}76.5 \\
76.2\end{array}$ & $\begin{array}{l}74.20 \\
72.50\end{array}$ \\
\hline Average. & $\begin{array}{l}\text { Control } \\
\text { Later }\end{array}$ & & $\begin{array}{r}139 \\
29\end{array}$ & $\begin{array}{l}43.7 \\
46.5\end{array}$ & $\begin{array}{l}79.77 \\
79.32\end{array}$ & $\begin{array}{l}76.37 \\
75.83\end{array}$ & $\begin{array}{l}73.67 \\
72.75\end{array}$ \\
\hline Whole blood. & $\begin{array}{l}\text { Control } \\
4^{\circ} 5^{\prime}\end{array}$ & $\begin{array}{r}0 \\
613\end{array}$ & $\begin{array}{r}146 \\
0\end{array}$ & $\begin{array}{l}39.3 \\
59.0\end{array}$ & $\begin{array}{l}82.20 \\
77.10\end{array}$ & $\begin{array}{l}70.20 \\
74.90\end{array}$ & $\begin{array}{l}69.15 \\
67.30\end{array}$ \\
\hline Whole blood. . & $\begin{array}{l}\text { Control } \\
7^{\circ} 35^{\prime}\end{array}$ & $\begin{array}{r}0 \\
1138\end{array}$ & $\begin{array}{l}168 \\
136\end{array}$ & $\begin{array}{l}44.0 \\
76.5\end{array}$ & $\begin{array}{l}79.30 \\
71.10\end{array}$ & $\begin{array}{l}76.10 \\
75.60\end{array}$ & $\begin{array}{l}74.85 \\
73.10\end{array}$ \\
\hline Whole blood. & $\begin{array}{l}\text { Control } \\
6^{\circ} 25^{\prime}\end{array}$ & $\begin{array}{r}0 \\
412\end{array}$ & $\begin{array}{r}150 \\
0\end{array}$ & $\begin{array}{l}47.3 \\
67.5\end{array}$ & $\begin{array}{l}79.35 \\
74.50\end{array}$ & $\begin{array}{l}77.15 \\
75.40\end{array}$ & $\begin{array}{l}74.80 \\
73.15\end{array}$ \\
\hline Average. . & $\begin{array}{l}\text { Control } \\
\text { Later }\end{array}$ & & $\begin{array}{r}155 \\
45\end{array}$ & $\begin{array}{l}42.9 \\
67.7\end{array}$ & $\begin{array}{l}80.28 \\
74.23\end{array}$ & $\begin{array}{l}74.48 \\
75.30\end{array}$ & $\begin{array}{l}72.93 \\
71.18\end{array}$ \\
\hline
\end{tabular}


It is rather surprising in the experiments in which solutions of salt or of glucose were injected and in which there was a decrease in the amount of total protein, albumin and globulin per unit volume of serum that there was usually at the same time a decrease in the volume of plasma in the blood stream. The smallest alterations in the plasma volume were associated with the giving of 20 per cent glucose solution. Since the plasma volume was usually reduced, the decrease in the percentage of protein was not due to simple dilution by the injected fluid. As both the percentage of protein and the volume of plasma were usually both reduced, the entire amount of protein in the blood stream was greatly diminished. In the experiments in which the six per cent gum acacia or the gum acacia-glucose solutions were injected, the findings were different in that they were usually associated with an increase in the plasma volume and the decrease in the percentage of protein was greater than that usually found if salt or glucose solutions were used. The gum acacia-glucose solution produced a greater increase in the volume of plasma than did the six per cent gum acacia. Even though the plasma volume was greatly increased in some of these experiments, there was always a decrease in the entire amount of protein. The nitrogen content of the gum acacia that was used was found to be negligible. The values for protein in these experiments are misleading in that they do not give a true estimate of the osmotic pressure that the serum was capable of exerting since six per cent gum acacia has an osmotic pressure approximately the same as that of blood serum. The gum acacia that was present in the blood stream at any given time was not determined.

The results obtained in the studies of the effects of the injection of blood serum and whole blood differed from the others mainly in that the concentration of protein in the serum of the blood stream did not decrease. In two of the three experiments in which blood serum was introduced there was a decrease in the plasma volume and in the entire amount of serum protein, although enormous amounts of serum had been injected. In the experiments in which whole blood was administered, there was a tremendous increase in the concentration of the red blood cells and probably a decrease in the plasma volume.

It has been known for a long time that solutions of crystalloids leave the blood stream shortly after having been injected. That the injection of these solutions in the presence of gross capillary injury following trauma would result in a great decrease in the protein content of the blood plasma as well as in the volume of plasma has not been appreciated. Since the osmotic pressure in the vessels is maintained largely by the protein, the significance of the alterations is apparent. If the blood pressure and the plasma volume were the same in two animals one of which had and one of which had not received injections of solutions of crystalloids in large quantities, it is believed that the chances of recovery would be greater in 
the animal that had not received the fluid since the protein content of the serum would not be decreased. This point could not be determined in these experiments as all of the animals died as a result of the long duration of the trauma and the depth of the anesthesia. Very little if any difference in the rapidity of the fall of the blood pressure was observed in the experiments on intestinal trauma alone and those in which both trauma and the injection of fluid were carried out. Perhaps the survival period of the latter group was a little longer but the difference was not great. In an animal in which the intestines had been traumatized for a long period, if the injection of crystalloid solutions was stopped, we have the distinct impression that the blood pressure declined more rapidly than in an animal in a similar condition in which no fluid had been introduced. We do not mean to imply if a patient is in shock as the result of an injury and no donor is obtainable that saline or similar solutions should not be injected. However, in the absence of a favorable response in the blood pressure after a considerable amount of solution had been injected, almost certainly the further administration of the same fluid intravenously would diminish the chances of recovery.

As has been stated previously, the total quantity of fluid injected in most of the experiments was quite large but frequent analyses were performed and in this way the effects of small amounts were also determined. There seems to be a tendency at the present time to use very large quantities of fluids intravenously in treating patients. In reporting their results with the use of normal salt solution in treating shock, MacFee and Baldridge (10) recently stated, "The solution has been given intravenously in amounts ranging from 2000 cc. to 8000 cc. at a single injection."

The gum acacia solutions that were injected presented the distinct advantage over the solutions of crystalloids in that they were associated with an increase in plasma volume rather than a decrease. It is quite true that the protein content of the serum was decreased to a lower value in these experiments than in any others, but the functions of the protein in maintaining the osmotic pressure of the circulating blood were probably taken over at least partially by the gum acacia which is a colloid and hence exerts an osmotic pressure. We do not know how much gum acacia was in the circulation at any one time or how long it remained there. Concerning the fate of gum acacia, Bayliss (11) states, "I have obtained the pentose test in the blood twenty-four hours after injection, but it had disappeared in three weeks. If eliminated in the urine, the process is very slow, since the urine collected for six hours after injection gave no reaction, even when concentrated."

When whole blood was injected continuously while the intestines were being traumatized, there was a tremendous increase in the concentration of the red blood cells. This was to be expected since the loss of 
red blood cells at the site of the trauma was small as compared with the loss of plasma. The effects that may result when the blood becomes greatly concentrated have been described by Underhill in numerous publications.

The injection of blood serum was associated with the smallest alterations in the composition of the blood. The percentage of protein per unit volume of serum and the plasma volume were not changed greatly in these experiments. There was a large loss of protein in the fluid that escaped but due to the fact that serum was being injected, the lost protein of the blood serum was replaced.

The greatest part of the fluid that was lost from the circulation escaped through the capillaries of the injured area. Determinations of the water content of skeletal muscle showed that it did not escape into them. In most instances in which 3.0 per cent salt solution was injected, the dogs passed fluid from the rectum. The amount of fluid and of nitrogen that escaped in the urine was not very great in most of the experiments. Edema of the lungs was noted several times at autopsy.

\section{SUMMARY}

All of the experiments were performed on dogs that were deeply anesthetized by sodium barbital. Shock was produced by continuously passing the intestines between the fingers. Blood serum and the fluid that escaped into the peritoneal cavity were collected frequently for the studies.

In the first group of experiments studies were performed on the blood serum and the peritoneal fluid during continuous trauma to the intestines. No fluid was administered. Among the findings were the following. There was a great diminution in the volume of plasma in the circulation. (2) The protein content per unit volume of serum remained approximately the same throughout the experiments. (3) The total protein content of the blood serum and the peritoneal fluid were approximately the same in all instances. (4) The content in albumin of the peritoneal fluid was usually greater than that of the blood serum and the content in globulin was less.

In the second group of experiments various solutions were injected intravenously at a constant speed while the intestines were being traumatized. The solutions included (1) 0.9 per cent saline, (2) 3.0 per cent saline, (3) 6.0 per cent glucose, (4) 20.0 per cent glucose, (5) 6.0 per cent gum acacia, (6) a solution of 6.0 per cent gum acacia and 20.0 per cent glucose in normal saline, (7) blood serum and (8) whole blood. Among the findings were the following. (1) The total protein content of the blood serum and the peritoneal fluid that were collected simultaneously was approximately the same in all experiments. (2) The albumin content of the peritoneal fluid was usually greater than that of the blood 
serum while the globulin content was less. (3) The injection of the solutions of salt and glucose was usually associated with a decrease in the percentage of protein per unit volume of serum, a diminution of the volume of plasma in the circulation and a great decrease in the absolute plasma protein. (4) When the solutions of gum acacia were injected, there was a decrease in the percentage of protein, an increase in the plasma volume and a decrease in the absolute amount of plasma protein.

The injection of blood serum was associated usually with comparatively small alterations in the percentage of protein, the volume of plasma and the absolute amount of plasma protein. (6) When whole blood was injected, there was very little alteration in the percentage of protein in the blood serum. Since there was a tremendous increase in the concentration of the blood, there was probably a rather large reduction in the plasma volume and in the absolute amount of plasma protein.

\section{BIBLIOGRAPHY}

1. Cannon, W. B., Traumatic Shock. D. Appleton \& Co., New York, 1923, p. 177.

2. Blalock, Alfred, Arch. Surg., 1931, xxii, 314. Trauma to the Intestines. The Importance of the Local Loss of Fluid in the Production of the Low Blood Pressure.

3. Folin, O., and Wu, Hsien, J. Biol. Chem., 1919, xxxviii, 81. A System of Blood Analysis.

4. Howe, P. E., J. Biol. Chem., 1921, xlix, 109. The Determination of the Proteins in Blood-A Micro Method.

5. Gunning, J. W., Ztschr. f. Anal. Chem., 1889, xxviii, 188. Ueber eine Modification der Kjeldahl-Methode.

6. Cohen, B., and Smith, A. H., J. Biol. Chem., 1919, xxxix, 489. The Colorimetric Determination of Hemoglobin.

7. Harris, P. N., and Blalock, Alfred, Arch. Surg., 1931, xxii, 638. Experimental Shock. X. Observations on the Water Content of the Tissues of the Body After Trauma and After Hemorrhage.

8. Beard, J. W., and Blalock, Alfred, Arch. Surg., 1931, xxii, 617. Experimental Shock. VIII. The Composition of the Fluid that Escapes from the Blood Stream After Mild Trauma to an Extremity, After Trauma to the Intestines and After Burns.

9. White, H. L., and Erlanger, J., Am. J. Physiol., 1920, liv, 1. The Effect on the Composition of the Blood of Maintaining an Increased Blood Volume by the Intravenous Injection of a Hypertonic Solution of Gum Acacia and Glucose in Normal, Asphyxiated and Shocked Dogs.

10. MacFee, W. F., and Baldridge, R. R., Ann. Surg., 1930, xci, 329. Postoperative Shock and Shock-Like Conditions. Treatment by Infusion in Large Volume.

11. Bayliss, W. M., Report of Shock Committee, Medical Research Committee, Report I, 1918, p. 13. Intravenous Injections to Replace Blood. 